\title{
Acaricides efficiency on Rhipicephalus (Boophilus) microplus from Bahia state North-Central region
}

\author{
Eficiência de acaricidas sobre Rhipicephalus (Boophilus) microplus na região Centro-Norte, Bahia \\ José Tadeu Raynal ${ }^{1}$; Aretha Alves Borges da Silva²; Thiago de Jesus Sousa ${ }^{3}$; \\ Thiago Campanharo Bahiense ${ }^{4}$; Roberto Meyer ${ }^{4}$; Ricardo Wagner Portela ${ }^{4 *}$ \\ ${ }^{1}$ Ciência Animal nos Trópicos, Escola de Medicina Veterinária e Zootecnia, Universidade Federal da Bahia - UFBA, Salvador, BA, Brasil \\ ${ }^{2}$ Medicina Veterinária, Escola de Medicina Veterinária e Zootecnia, Universidade Federal da Bahia - UFBA, Salvador, BA, Brasil \\ ${ }^{3}$ Biotecnologia, Instituto de Ciências da Saúde, Universidade Federal da Bahia - UFBA, Salvador, BA, Brasil \\ ${ }^{4}$ Departamento de Biointeração, Instituto de Ciências da Saúde, Universidade Federal da Bahia - UFBA, Salvador, BA, Brasil
}

Received May 21, 2012

Accepted October 15, 2012

\begin{abstract}
The cattle tick Rhipicephalus (Boophilus) microplus is responsible for major losses in the Brazilian livestock, mainly due to reduction in cattle productive performance. Resistance development to major classes of acaricide widely used nowadays has been extensively reported, as well as the occurrence of residues from these compounds in animal products and the environment. This study aimed to evaluate the efficiency of acaricides on $R$. (B.) microplus collected from rural properties in the North-Central region of Bahia State. Ticks were collected in several cattle farms in the cited region, and an in vitro acaricide efficiency assay was performed based on the immersion of ticks in acaricide solutions made according to manufacturers' recommendations. The results obtained in the experiments indicated varying degrees of efficiency of the several bases studied, with the products benzofenilurea, macrocyclic lactone and fipronil showing the highest levels of efficiency, $100 \%, 100 \%$ and $97.34 \%$, respectively. It was possible to conclude that, for the region studied, there are different degrees of commercial acaricides efficiency, and many present less than $95 \%$ effectiveness, value determined as acceptable by the Brazilian legislation.
\end{abstract}

Keywords: Ticks, cattle, drug resistance, acaricide, Brazilian Northeast.

\section{Resumo}

O carrapato Rhipicephalus (Boophilus) microplus é responsável por grandes perdas na pecuária brasileira, principalmente devido à redução no desempenho produtivo dos animais. A resistência do parasita a diferentes classes de acaricidas tem sido amplamente relatada, bem como os problemas de ocorrência de resíduos desses compostos em produtos de origem animal e no ambiente. Esse estudo teve como objetivo avaliar a eficiência de diversos acaricidas sobre populaçôes de $R$. (B.) microplus provenientes de propriedades rurais da Região Centro-Norte do Estado da Bahia, Brasil. Teleóginas ingurgitadas foram colhidas em diferentes propriedades da regiáo e submetidas a ensaio in vitro de eficiência de acaricidas, baseado na imersão dos carrapatos em soluçōes de acaricidas feitas seguindo as recomendações dos fabricantes. Os resultados obtidos indicam níveis variados de eficiência das bases estudadas, com os acaricidas benzofenilureia, lactona macrocíclica e fipronil apresentando os índices mais altos de eficiência, 100\%, 100\% e 97.34\%, respectivamente. Pode-se concluir que, para a região estudada, os acaricidas apresentam níveis diversos de eficiência, e muitos deles possuem eficácia de menos de $95 \%$, como recomendado pela legislaçáo brasileira.

Palavras-chave: Carrapatos, bovinos, resistência, carrapaticidas, Nordeste.

\section{Introduction}

Several damages caused by parasites in cattle herd lead to drop in production in tropical and subtropical countries (PATARROYO et al., 2002; PEREIRA, 2006). The tick $R$. (B.) microplus (Canestrini, 1887) (Acari: Ixodidae) is a major ectoparasite of cattle, causing many problems in national livestock,

\footnotetext{
*Corresponding author: Ricardo Wagner Portela

Instituto de Ciências da Saúde, Universidade Federal da Bahia - UFBA,

Av. Miguel Calmon, s/n, Vale do Canela, Salvador, BA, Brasil

e-mail: rwportela@gmail.com
}

which causes efficiency and productivity losses in these animals, besides being vectors of pathogens causing various diseases (BROWN et al., 2006; JONSSON, 2006; JONSSON et al., 2008).

In Brazil, parasite-related losses are estimated at about 1 billion dollars per year, resulted from the direct action of the parasite and the cost of control systems, the latter representing annual expenditures of approximately US\$800 million in chemicals to combat parasites (FURLONG et al., 2004). The Brazilian cattle herd is composed of taurine, zebu and crossbred races, each one presenting different 
susceptibilities to the development of ticks' parasitic stages, and there are climatic conditions favorable to the survival and development of its non-parasitic stages (CORDOVÉS, 1997).

Chemical control of ticks has been characterized by continuous increase of resistance, with consequent increase in the frequency of acaricides application and the presence of residues of these products in milk and meat (VARGAS et al., 2003; CAMPOS JUNIOR; OLIVEIRA, 2005; MENDES, 2005). A chemical base tick must present more than $95 \%$ efficacy on a sensitive strain of $R$. (B.) microplus to be licensed by the Brazilian government (BRASIL, 1987). Thus, tick control strategies are considered as being a combination of prudent and rational use of the chemical bases currently available and the frequency of its application, leading to the maintenance of parasite populations below their economic damage threshold, and with a minimal environmental impact (FAO, 2003).

In the North-Central region of Bahia State, there is no data record demonstrating acaricides efficacy for $R$. (B.) microplus control. The detection of the resistance of ticks is essential to choose a proven effective product for the control of ectoparasites. Obtaining a regional profile of the problem of resistance to acaricides could serve as background for the planning of parasite control measures. Based on the assumption that there are populations of $R$. (B.) microplus in the North-Central region of Bahia State presenting varying levels of resistance against the acaricides available in the market, this study aimed to evaluate the in vitro efficacy of various drugs on $R$. (B.) microplus.

\section{Materials and Methods}

Engorged $R$. (B.) microplus females, identified as suggested by Aragáo and Fonseca (1961), with length equal to or greater than $4 \mathrm{~mm}$, were collected directly from several body parts of naturally infested cattle of various breeds and blood levels, in rural properties in the North-Central region of Bahia State. These procedures were conducted forty-five days after the last acaricide treatment. The Figure 1 depicts the North-Central region of Bahia State and the municipalities studied, which were chosen because they presented the largest cattle herds in the region (IBGE, 2009). Three hundred ticks were collected in each property at two different moments. Ten groups of twenty ticks each were separated, with the size and weight of the gravid females observed for this separation to make it as equitable as possible.

After that, the tick immersion assay (PATARROYO et al., 2002) was performed with slight modifications. Briefly, each group of twenty ticks was wrapped in surgical gauze and immersed in acaricide solution. The nine pharmacological bases used and their concentrations are listed in Table 1. All dilutions were made in accordance with the manufacturers' recommendations, with final volume of $100 \mathrm{~mL}$ for each group, using distilled water as control. A positive control of the fipronil solution was prepared by diluting $0.031 \mathrm{~g}$ of Regent $800 \mathrm{WG}$ (BASF, California) in $40 \mathrm{~mL}$ acetone and $60 \mathrm{~mL}$ of distilled water, obtaining a final concentration of $25 \mu \mathrm{g} / \mathrm{mL}$; also, a negative control was made for this group, where ticks were immersed in a solution of $40 \mathrm{~mL}$ acetone and $60 \mathrm{~mL}$ of distilled water. The neem extract was composed by a commercial solution of neem plant (Azadirachta indica - Meliaceae Family) extract at a $1.2 \%$ concentration. After five minutes of immersion, ticks were dried with absorbent paper and individually placed in 24 well plates (TPP), and incubated in a BOD chamber at $27^{\circ} \mathrm{C}$ and $80 \%$ humidity for a 15 -day period. After that, the egg mass of each female was weighted. Each oviposition was replaced at the BOD chamber $\left(27^{\circ} \mathrm{C}\right.$ and $80 \%$ humidity) in test tubes sealed with hydrophilic cotton and incubated for another 30 days, the eggshells were then weighted to predict the larvae weight (DE LA FUENTE, 1995).

The efficiency of acaricides was calculated as described by Patarroyo et al. (2002), taking into account the weight of eggs and larvae of the experimental groups compared to the control group, as described next:

$$
\begin{aligned}
& \text { Reduced Oviposition }(\mathrm{RO})=\left(1-\left(\frac{\text { oviposition weight of the test }}{\text { oviposition weight control }}\right)\right) \times 100 \\
& \text { Reduced Efficience }(\mathrm{RE})=\left(1-\left(\frac{\text { larval weight of the test }}{\text { larval weight control }}\right)\right) \times 100
\end{aligned}
$$

\section{Final Efficiency $=(\mathrm{RO} \times \mathrm{RE}) \times \mathbf{1 0 0}$}

Statistical analyses were performed using SPSS v-18 software. The differences between the efficiencies of each acaricide tested and the control group were identified by variance analysis (ANOVA) with subsequent application of the Tukey test, with significance set at $\mathrm{p}<0.05$.

Table 1. Acaricides used in the experiment, with their respective chemical groups, and the work concentrations recommended by the

\begin{tabular}{|c|c|c|}
\hline Acaricide & Group & Concentration used \\
\hline Cypermethrin & Pyrethroid & $0.15 \mathrm{mg} / \mathrm{mL}$ \\
\hline Deltamethrin & Pyrethroid & $0.5 \mathrm{mg} / \mathrm{mL}$ \\
\hline Amitraz & Amitrazin & $0.25 \mathrm{mg} / \mathrm{mL}$ \\
\hline Dichlorvos and Clorpirifos & Organophosphate & $1.5 \mathrm{mg} / \mathrm{mL}$ and $0.5 \mathrm{mg} / \mathrm{mL}$ \\
\hline Dichlorvos and Cypermethrin & Organophosphate and Pyrethroid & $1.25 \mathrm{mg} / \mathrm{mL}$ and $0.12 \mathrm{mg} / \mathrm{mL}$ \\
\hline Fluazuron & Benzofenilureas & $25 \mathrm{mg} / \mathrm{mL}$ \\
\hline Ivermectin & Avermectin & $5 \mathrm{mg} / \mathrm{mL}$ \\
\hline Fipronil & Fenilpirazoles & $0.25 \mu \mathrm{g} / \mathrm{mL}$ \\
\hline Extract of the neem plant (extracted from $A$ indica-Meliaceae Family - 1.2\%) & Tetranortriterpenoids & $1: 200$ \\
\hline
\end{tabular}
manufacturers, which were used in this study. 


\section{Results}

The average acaricides efficiency recorded in the municipalities in the North-Central region of Bahia is described in Table 2. Cypermethrin, deltamethrin, amitraz, dichlorvos and chlorpyrifos association, dichlorvos and cypermethrin association and neem plant $(A$. indica) extract showed efficiency equal to zero in some sampled counties, and below the values determined as acceptable by the Brazilian legislation in others. Ivermectin, fipronil and fluazuron showed better results, sometimes higher than $96.14 \%$ efficiency, in most of the counties recorded.

The efficiencies of the tested pharmacological bases in a specific property in the municipality of Miguel Calmon are shown in Table 3, where it is possible to observe low efficacy of acaricides, also revealing resistance to fipronil.

Figure 2 shows the average efficiency values obtained in all the municipalities studied in the North-Central region of Bahia State.
It shows that fipronil, ivermectin and fluazuron reached the highest levels of efficiency across the region, with no statistical difference between them in the statistical test (Tukey), with $p<0.001$. Amitraz appeared as the basis that presented intermediate levels of performance, different from control $(0 \%)$ with $p<0.05$. None of the other acaricides (cypermethrin, deltamethrin, dichlorvos and chlorpyrifos, dichlorvos and cypermethrin and neem extract) showed statistical differences, when compared to the control group.

\section{Discussion}

The North-Central region of Bahia State has a 1,642,583 cattle herd, and the number of animals in the studied municipalities corresponds to 221,631 heads (IBGE, 2009), equivalent to $13.49 \%$ of the cattle herd in the region. These data demonstrate that the above-cited region is of great importance in the cattle breeding scenario of the State of Bahia.

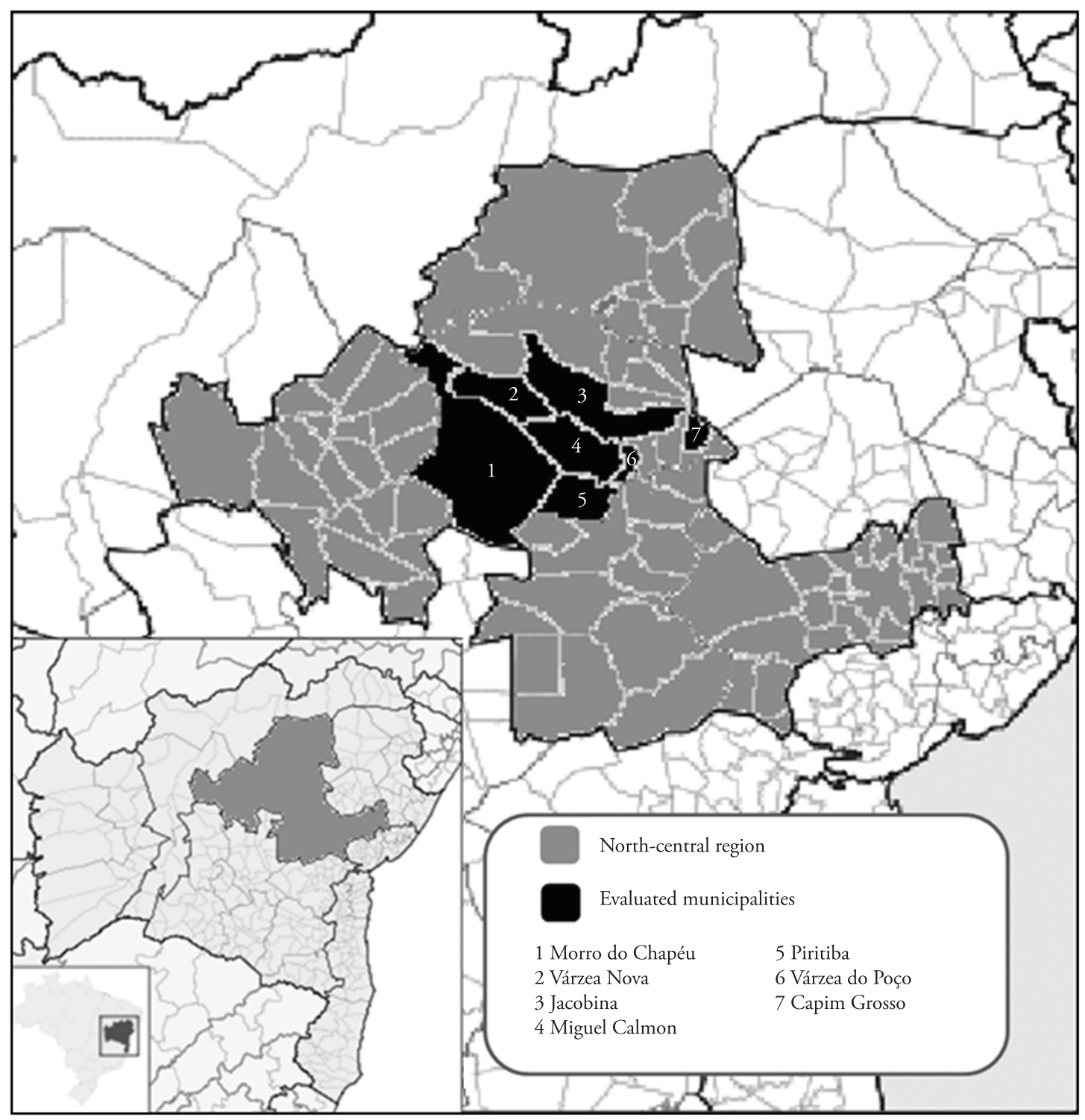

Figure 1. Sampled area in the North-Central region of Bahia State. The studied municipalities are detached in bold. 
Table 2. Efficiency levels of several acaricides on $R$. (B.) microplus from the North-Central region of Bahia State, Brazil. Results are expressed in percentage $(\%)$, followed by the confidence interval $(5 \%)$.

\begin{tabular}{|c|c|c|c|c|c|c|c|}
\hline \multirow[b]{2}{*}{ Acaricide } & \multicolumn{7}{|c|}{ Municipalities } \\
\hline & $\begin{array}{l}\text { Miguel } \\
\text { Calmon }\end{array}$ & Jacobina & Piritiba & Capim Grosso & $\begin{array}{c}\text { Várzea do } \\
\text { Poço }\end{array}$ & $\begin{array}{l}\text { Morro do } \\
\text { Chapéu }\end{array}$ & Várzea Nova \\
\hline Cypermethrin & $\begin{array}{c}30.49 \\
(28.97-32.02)\end{array}$ & $\begin{array}{c}28.10 \\
(26.70-29.51)\end{array}$ & 0 & $\begin{array}{c}19.18 \\
(18.22-20.14)\end{array}$ & 0 & $\begin{array}{c}19.49 \\
(18.52-20.47)\end{array}$ & $\begin{array}{c}10.99 \\
(10.44-11.53)\end{array}$ \\
\hline Deltamethrin & $\begin{array}{c}22.57 \\
(21.44-23.69)\end{array}$ & $\begin{array}{c}4 ., 83 \\
(39.73-43.92)\end{array}$ & 0 & $\begin{array}{c}21.45 \\
(20.38-22.52)\end{array}$ & $\begin{array}{c}0.07 \\
(0.07-0.07)\end{array}$ & $\begin{array}{c}26.15 \\
(24.84-27,45)\end{array}$ & $\begin{array}{c}14.82 \\
(14.08-15.56)\end{array}$ \\
\hline Amitraz & $\begin{array}{c}41.33 \\
(39.26-43.39)\end{array}$ & $\begin{array}{c}31.17 \\
(29.61-32.73)\end{array}$ & $\begin{array}{c}59.53 \\
(56.55-62.50)\end{array}$ & $\begin{array}{c}40.00 \\
(38.00-42.00)\end{array}$ & $\begin{array}{c}11.02 \\
(10.47-11.57)\end{array}$ & $\begin{array}{c}36.15 \\
(34.34-37.96)\end{array}$ & $\begin{array}{c}1.66 \\
(1.57-1.74)\end{array}$ \\
\hline $\begin{array}{l}\text { Dichlorvos and } \\
\text { Clorpirifos }\end{array}$ & $\begin{array}{c}51.20 \\
(48.64-53.76)\end{array}$ & $\begin{array}{c}55.15 \\
(52.39-57.90)\end{array}$ & 0 & $\begin{array}{c}48.18 \\
(45.77-50.59)\end{array}$ & $\begin{array}{c}63.46 \\
(60.29-66.64)\end{array}$ & $\begin{array}{c}43.99 \\
(41.79-46.19)\end{array}$ & $\begin{array}{c}50.17 \\
(47.66-52,68)\end{array}$ \\
\hline $\begin{array}{l}\text { Dichlorvos and } \\
\text { Cypermethrin }\end{array}$ & $\begin{array}{c}18.34 \\
(17.42-19.26)\end{array}$ & $\begin{array}{c}29.87 \\
(28.38-31.37)\end{array}$ & 0 & $\begin{array}{c}38.08 \\
(36.18-39.99)\end{array}$ & $\begin{array}{c}9.79 \\
(9.30-10.28)\end{array}$ & $\begin{array}{c}37.62 \\
(35.74-39.50)\end{array}$ & $\begin{array}{c}3.57 \\
(3.39-3,75)\end{array}$ \\
\hline Fluazuron & $\begin{array}{c}100.00 \\
(95.00-100)\end{array}$ & $\begin{array}{c}100.00 \\
(95.00-100)\end{array}$ & $\begin{array}{c}100.00 \\
(95.00-100)\end{array}$ & $\begin{array}{c}100.00 \\
(95.00-100)\end{array}$ & $\begin{array}{c}100.00 \\
(95.00-100)\end{array}$ & $\begin{array}{c}100.00 \\
(95.00-100)\end{array}$ & $\begin{array}{c}100.00 \\
(95.00-100)\end{array}$ \\
\hline Ivermectin & $\begin{array}{c}100.00 \\
(95,00-100)\end{array}$ & $\begin{array}{c}100.00 \\
(95.00-100)\end{array}$ & $\begin{array}{c}100.00 \\
(95.00-100)\end{array}$ & $\begin{array}{c}100.00 \\
(95.00-100)\end{array}$ & $\begin{array}{c}100.00 \\
(95.00-100)\end{array}$ & $\begin{array}{c}100.00 \\
(95.00-100)\end{array}$ & $\begin{array}{c}100.00 \\
(95.00-100)\end{array}$ \\
\hline Fipronil & $\begin{array}{c}96.14 \\
(91.33-100)\end{array}$ & $\begin{array}{c}98.09 \\
(93.19-100)\end{array}$ & $\begin{array}{c}100.00 \\
(95.00-100)\end{array}$ & $\begin{array}{c}100.00 \\
(95.00-100)\end{array}$ & $\begin{array}{c}99.48 \\
(94.51-100)\end{array}$ & $\begin{array}{c}99.22 \\
(94.26-100)\end{array}$ & $\begin{array}{c}97.99 \\
(93.09-100)\end{array}$ \\
\hline $\begin{array}{l}\text { Extract of the neem } \\
\text { plant }\end{array}$ & $\begin{array}{c}6.49 \\
(96.16-96.81)\end{array}$ & $\begin{array}{c}25.97 \\
(24.68-27.27)\end{array}$ & 0 & $\begin{array}{c}22.84 \\
(21.70-23.99)\end{array}$ & $\begin{array}{c}8.57 \\
(8.14-9.00)\end{array}$ & $\begin{array}{c}22.85 \\
(21.71-23.99)\end{array}$ & $\begin{array}{c}12.69 \\
(12.05-13.32)\end{array}$ \\
\hline
\end{tabular}

Table 3. Acaricides efficiency levels on $R$. (B.) microplus from a private property in the municipality of Miguel Calmon, Bahia State. Results are expressed in percentage (\%), followed by the confidence interval (5\%).

\begin{tabular}{lc}
\hline \multicolumn{1}{c}{ Acaricides } & efficiency of the Acaricide (\%) \\
\hline Cypermethrin & $0.67(0.63-0.70)$ \\
Deltamethrin & $1,35(1.28-1.42)$ \\
Amitraz & $15.80(15.01-16.59)$ \\
Dichlorvos and Clorpirifos & $22.15(21.04-23.26)$ \\
Dichlorvos and Cypermethrin & $2.82(2.68-2.96)$ \\
Fluazuron & $100(95.00-100)$ \\
Ivermectin & $100(95.00-100)$ \\
Fipronil & $86.54(82.22-90.87)$ \\
Extract of the neem plant & $2.83(2.69-2.97)$ \\
\hline
\end{tabular}

Ours results showed it is possible to observe a variation of resistance to acaricides in each evaluated municipality, which is justified on the basis of the ways and times of various applications; random use of chemical bases; and inappropriate acaricide management. This can consequently select ticks that naturally possess the resistance gene for to the pharmacological product, and such feature is transmitted to future generations.

In other studies, cypermethrin showed an efficacy ranging from $41.27 \%$ to $64.16 \%$ in the municipality of Ibiúna (São Paulo State) (MENDES et al., 2007) and, also in São Paulo, it was showed that $82.6 \%$ and $86.36 \%$ of the $R$. (B.) microplus population showed resistance to cypermethrin and deltamethrin (MENDES et al., 2011), respectively. In the State of Bahia, in the municipalities of Ilhéus and Itamaraju, it was found that deltamethrin showed
65.04\% (CAMPOS JUNIOR; OLIVEIRA, 2005) and 33.90\% (SPAGNOL et al., 2010) effectiveness, respectively. In a study conducted in the Vale do Paraíba, State of Sao Paulo, it was demonstrated that deltamethrin treatment presented efficiency of about 28.24\% (PEREIRA, 2006). These data show that the resistance of $R$. (B.) microplus to two pyrethroids in the present study can vary in different parts of the country, and the treatment with these bases may be ineffective for the control of parasitic tick populations in different localities.

In already published studies with amitrazin conducted in other Brazilian states, such as Pernambuco (FAUSTINO et al., 1995) and Rio Grande do Sul (VIEIRA et al., 1998); it was found efficacy rates of $81.94 \%$ and $91.50 \%$, respectively. In Bahia State, $49 \%$ efficiency (SPAGNOL et al., 2010) was found in the municipality of Itamaraju. Although this study demonstrated low efficiency of the amitrazin acaricide, it still presents good efficiency in other states and regions of Brazil, so it should still be considered as an option in tick control. In this way, chemical treatments should be preceded by a tick test.

Tests of efficiency with the association of two organophosphates presented variable effectiveness levels. Mendes et al. (2007) observed efficiencies ranging from $85.31 \%$ to $100 \%$ in Ibiúna, in the State of Sao Paulo, and 81.4\% efficacy (SPAGNOL et al., 2010) was found in Itamaraju, State of Bahia. In the Brazilian State of Minas Gerais, studies found a general efficacy of $96.63 \%$ (ARANTES et al., 1995) and 76.7\% (DAHER et al., 2012). In the State of Sao Paulo, Coumaphos efficacy ranged from $57.01 \%$ to $70.28 \%$ (MENDES et al., 2001). In this study, low levels of efficacy were observed for the combination of the two 


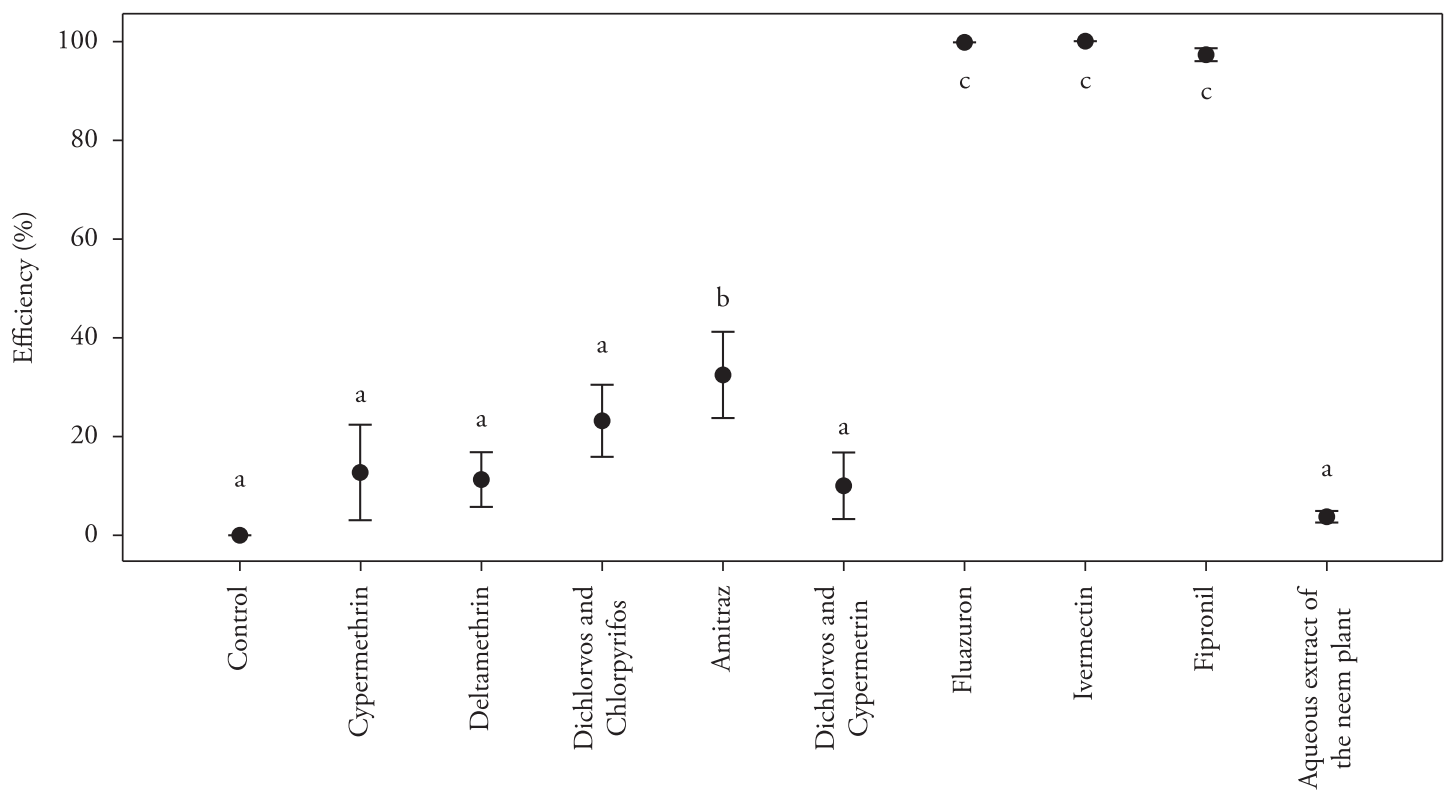

Figure 2. Average efficiency of acaricides on $R$. (B.) microplus from the North-Central region of Bahia State, Brazil. Results express the average efficiency obtained from all samples collected in the region after each in vitro acaricide treatment, and bars indicate the standard errors. Different superscript letters indicate statistically significant difference among the efficiency rates, by the ANOVA test, followed by Tukey test. Between $\mathrm{a}$ and $\mathrm{b}-p<0.05$; between $\mathrm{c}$, and $\mathrm{a}$ and $\mathrm{b}-p<0.001$.

organophosphates, which can be caused due to inappropriate and continuous use of these bases in the studied region.

One option for the control of the $R$. (B.) microplus tick is the association of two different pharmacological bases, and this presentation is largely found at the commercial level. The association evaluated in this test involved an organophosphate and a pyrethroid. Some published reports concerning the efficacy of this type of association can be found, as it could be seen that in Bahia State, municipality of Ilhéus, the efficacy was of about 75.73\% (CAMPOS JUNIOR; OLIVEIRA, 2005) and efficiency ranged from $40.38 \%$ to $76.81 \%$ in Ibiúna, State of Sao Paulo (MENDES et al., 2007). In addition, in the present study, this association was not able to produce good levels of efficiency.

In this study, fluazuron presented high levels of efficiency. No reports were found regarding the resistance of $R$. (B.) microplus to the fluazuron pharmacological basis, but attention must be paid to the fact that if any product is not applied to the animals in an appropriate way and at a suitable time, the resistance will tend to appear.

Regarding ivermectin, reports described resistance in Mexico (PEREZ-COGOLLO et al., 2010) and the field experiment reported by Martins and Furlong (2001) discovered a strain resistant to avermectins in the State of Rio Grande do Sul; also, this same situation was already described in reports in the states of São Paulo and Mato Grosso do Sul (CASTRO-JANER et al., 2010b).

In this study, fipronil showed high degree of efficiency, being fully considered within the parameters recommended by the Brazilian Ministry of Agriculture. In Uruguay (CASTRO-JANER et al., 2010a), in the Brazilian states of Rio Grande do Sul, Mato Grosso do Sul and São Paulo, the existence of fipronil resistant strains (CASTRO-JANER et al., 2010b) was also shown. This situation points to the fact that this drug must be carefully used by Bahia
State herd owners, since the inadequate application can lead to the development of resistant ticks.

The extract of the neem plant did not show appropriate results in this study; other reports have shown $30.0 \%$ efficacy in the semi-arid region of Paraiba State (SILVA et al., 2007). In India, it was found $31.2 \%$ to $76.1 \%$ effectiveness against $R$. (B.) microplus (SRIVASTAVA et al., 2008; MAGADUM et al., 2009). The biochemical effects of this extract over the cattle tick remains unclear, but Habluetzel et al. (2007) found that the extract produced a reduction in the survival of the larvae and adults and also interfered with oviposition and oogenesis, behavior, dietary process, and growth of arthropods (SCHMUTTERER, 1990; MORDUE; NISBET, 2000; BROGLIO-MICHELETTI et al., 2009, 2010).

The results reported herein can serve as a basis for direct tests of acaricide resistance in the region, and also to guide farmers on what type of base to use in their region. Even so, several bases presented different degrees of effectiveness depending on the municipality, and should be considered and added in efficacy trials in each city or production unit to better understand the type of control to be conducted, and also to base the decision about the cost-benefit relationship. Moreover, it is also necessary to consider the indices of relative humidity, rainfall and temperature in the region studied, as a basis for drawing a map, which will advise on what would be the best time for the application of high efficiency bases, and also guide on the correct application frequency of these drugs. With these actions, a decrease in the number of applications would be expected, as well as a reduction in personnel expenses, and losses in animal performance. It should be also considered the production of milk and meat without or with less chemical waste, reduced environmental impact and lower risk of animals and employees poisoning. 


\section{Conclusions}

Rhipicephalus (Boophilus) microplus from the Bahia State North-Central region presents a high degree of resistance to organophosphates (23.18\% efficiency), pyrethroids (cypermethrin and deltamethrin, $12.67 \%$ and $11.13 \%$ efficiency, respectively), association organophosphate-pyrethroid (23.18\% efficiency), amitrazin (32.35\% efficiency) and neen plant aqueous extract (3.74\% efficiency). Acceptable levels of efficiency associated to the use of benzofenilurea, macrocyclic lactones (avermectins) and fipronil were observed.

\section{Acknowledgements}

The authors are profoundly grateful to Mrs. Francisca Soares, from the Laboratory of Immunology and Molecular Biology (LABIMUNO), for the technical assistance, and to the professors Flavia McBride and Samira Abdallah Hanna for equipment disposing. R Meyer is a Research Fellow from FAPEX, and RW Portela is a Pos-doc fellow from CAPES.

\section{References}

Aragão H, Fonseca F. Notas de Ixodologia. VIII. Lista e chave para os representantes da fauna ixodológica brasileira. Mem Inst Oswaldo Cruz 1961; 59(2): 115-130. PMid:13861962. http://dx.doi. org/10.1590/S0074-02761961000200001

Arantes GJ, Marques AO, Horner MR. O carrapato do bovino, Boophilus microplus, no município de Uberlândia, MG: Análise da sua resistência contra carrapaticidas comerciais. Rev Bras Parasitol Vet 1995; 4(2):89-93.

Brasil. Ministério da Agricultura. Normas para registros de parasiticidas de uso pecuário na Brasil. Brasília: Ministério da Agricultura; 1987.

Broglio-Micheletti SMF, Valente ECN, Souza LA, Dias NS, Araújo AMN. Plant extracts in control of Rhipicephalus (Boophilus) microplus (Canestrini, 1887) (Acari: Ixodidae) in laboratory. Rev Bras Parasitol Vet 2009; 18(4): 44-48. PMid:20040208. http://dx.doi.org/10.4322/ rbpv.01804008

Broglio-Micheletti SMF, Dias NS, Valente ECN, Souza LA, Lopes DOP, Santos JM. Ação de extrato e óleo de nim no controle de Rhipicephalus (Boophilus) microplus (Canestrini, 1887) (Acari: Ixodidae) em laboratório. Rev Bras Parasitol Vet 2010; 19(1): 44-48. PMid:20385059. http://dx.doi. org/10.4322/rbpv.01901008

Brown WC, Norimine J, Knowles DP, Goff WL. Immune control of Babesia bovis infection. Vet Parasitol 2006; 138(1-2): 75-87. PMid:16510249. http://dx.doi.org/10.1016/j.vetpar.2006.01.041

Campos Júnior DA, Oliveira PR. Avaliação in vitro da eficiência de acaricidas sobre Boophilus microplus (Canestrini, 1887) (Acari: Ixodidae) de bovinos no município de Ilhéus, Bahia, Brasil. Cienc Rural 2005; 35(6): 1386-1392. http://dx.doi.org/10.1590/S010384782005000600025

Castro-Janer E, Rifran L, González P, Piaggio J, Gil A, Schumaker TTS. Rhipicephalus (Boophilus) microplus (Acari: Ixodidae) resistance to fipronil in Uruguay evaluated by in vitro bioassays. Vet Parasitol 2010a; 169(1-2): 172-177. PMid:20056329. http://dx.doi. org/10.1016/j.vetpar.2009.12.017
Castro-Janer E, Martins JR, Mendes MC, Namindome A, Klafke GM, Schumaker TTS. Diagnoses of fipronil resistance in Brazilian cattle ticks (Rhipicephalus (Boophilus) microplus) using in vitro larval bioassays. Vet Parasitol 2010b; 173(3-4): 300-306. PMid:20688434. http://dx.doi. org/10.1016/j.vetpar.2010.06.036

Cordovés, CO. Carrapato: controle ou erradicação. Porto Alegre: Guaíba Agropecuária; 1997. PMid:9379389.

Daher DO, Bertolluci AV, Guimarães AM, Rocha CMBM. Fatores Associados à Resistência do Rhipicephalus (Boophilus) microplus (CANESTRINI, 1887) no sul de Minas Gerais. Rev Verde 2012; 7(1):102 -115.

De la Fuente J. Recombinant Vaccines for the Control of Cattle Tick. Habana: Elfos Scientae; 1995.

Food and Agriculture Organization - FAO. Producción y Sanidad Animal. In: Food and Agriculture Organization - FAO. Resistencia a los antiparasitarios: Estado actual com énfasis en América Latina. Roma: FAO; 2003. p. 52.

Faustino MAG, Pena EJM, Gurgel AEB. Eficácia in vitro de produtos carrapaticidas em fêmeas ingurgitadas de cepas de Boophilus microplus da sub-regiáo da Zona da Mata de Pernambuco. Rev Bras Parasitol Vet 1995; 4(S1): 58.

Furlong J, Prata MC, Martins JR, Costa Junior LM, Costa JCR, Verneque RS. Diagnóstico in vitro da sensibilidade do carrapato Boophilus microplus a acaricidas. Rev Bras Parasitol Vet 2004; 13(S1): 305.

Habluetzel A, Carnevali F, Lucantoni L, Grana L, Attili AR, Archilei F, et al. Impact of the botanical insecticide Neem Azal ${ }^{\oplus}$ on survival and reproduction of the biting louse Damalinia limbata on angora goats. Vet Parasitol 2007; 144(3-4): 328-337. PMid:17161539. http://dx.doi. org/10.1016/j.vetpar.2006.10.013

Instituto Brasileiro de Geografia e Estatística - IBGE. Epi info [online]. 2009 [cited 2011 mar 04]. Available from: http://www.ibge. gov.br/estadosat/temas.php?sigla=ba\&tema=pecuaria2009.

Jonsson NN. The productivity effects of cattle tick (Boophilus microplus) infestation on cattle, with particular reference to Bos indicus cattle and their crosses. Vet Parasitol2006; 137(1-2): 1-10. PMid:16472920. http:// dx.doi.org/10.1016/j.vetpar.2006.01.010

Jonsson NN, Bock RE, Jorgensen WK. Productivity and health effects of anaplasmosis and babesiosis on Bos indicus cattle and their crosses, and the effects of differing intensity of tick control in Australia. Vet Parasitol 2008; 155(1-2):1-9. PMid:18472219. http://dx.doi. org/10.1016/j.vetpar.2008.03.022

Magadum S, Mondal DB, Ghosh S. Comparative efficacy of Annona squamosa and Azadirachta indica extracts against Boophilus microplus Izatnagar isolate. Parasitol Res 2009; 105(4): 1085-1091. PMid:19557436. http://dx.doi.org/10.1007/s00436-009-1529-3

Martins JR, Furlong J. Avermectin resistance of the cattle tick Boophilus microplus in Brazil. Vet Rec 2001; 149(2): 64. PMid:11488352.

Mendes MC, Veríssimo CJ, Kaneto CN, Pereira JR. Bioassays for measuring the acaricides susceptibility of cattle tick Boophilus microplus (Canestrini, 1887) in Sao Paulo State, Brazil. Arq Inst Biol 2001; 68(2): 23-27.

Mendes MC. Resistência do carrapato Boophilus microplus (Acari: Ixodidae) aos piretróides e organofosforados e o tratamento carrapaticida em pequenas fazendas [Tese]. Campinas: Universidade Estadual de Campinas; 2005. 
Mendes MC, Lima CKP, Prado ÂP. Determinação da frequência de realização de bioensaios para o monitoramento da resistência do carrapato Boophilus microplus (Acari: Ixodidae). Arq Inst Biol 2007; 74(2): 87-93.

Mendes MC, Lima CKP, Nogueira AHC, Yoshihara E, Chiebao DP, Gabriel FHL, et al. Resistance to cypermethrin, deltamethrin and chlorpyriphos in populations of Rhipicephalus (Boophilus) microplus (Acari: Ixodidae) from small farms of the State of São Paulo, Brazil. Vet Parasitol 2011; 178(3-4): 383-388. PMid:21306827. http://dx.doi. org/10.1016/j.vetpar.2011.01.006

Mordue AJ, Nisbet AJ. Azadirachtin from the Neem Tree Azadirachta indica: its Action Against Insects. An Soc Entomol Bras 2000; 29(4): 615-632. http://dx.doi.org/10.1590/S0301-80592000000400001

Patarroyo JH, Portela RW, De Castro RO, Couto Pimentel J, Guzman F, Patarroyo ME, et al. Immunization of cattle with synthetic peptides derived from the Boophilus microplus gut protein (Bm86). Vet Immunol Immunopathol 2002; 88(3-4): 163-172. http://dx.doi.org/10.1016/ S0165-2427(02)00154-X

Pereira JR. Eficácia in vitro de formulçóes comerciais de carrapaticidas em teleóginas de Boophilus microplus coletadas de bovinos leiteiros do Vale do Paraíba, Estado de São Paulo. Rev Bras Parasitol Vet 2006; 15(2): 45-48. PMid:16834895.

Perez-Cogollo LC, Rodriguez-Vivas RI, Ramirez-Cruz GT, Miller RJ. First report of the cattle tick Rhipicephalus microplus resistant to ivermectin in Mexico. Vet Parasitol 2010; 168(1-2): 165-169. PMid:19951828. http://dx.doi.org/10.1016/j.vetpar.2009.10.021
Schmutterer, H. Properties and potencial of natural pesticides from nim tree, Azadirachta indica. Annu Rev Entomol 1990; 35: 271-297. PMid:2405771. http://dx.doi.org/10.1146/annurev.en.35.010190.001415

Silva WW, Athayde ACR, Rodrigues OG, Araújo GMB, Santos VD, Silva Neto AB, et al. Efeitos do neem (Azadirachta indica A. Juss) e do capim santo [Cymbopogon citratus (DC) Stapf] sobre os parâmetros reprodutivos de fêmeas ingurgitadas de Boophilus microplus e Rhipicephalus sanguineus (Acari: Ixodidae) no semiárido paraibano. Rev Bras Pl Med 2007; 9(3): 1-5.

Spagnol FH, Paranhos EB, Albuquerque GR. Avaliação in vitro de acaricidas sobre Rhipicephalus (Boophilus) microplus Canestrini, 1887 (Acari: Ixodidae) de bovinos leiteiros no município de Itamaraju, Bahia, Brasil. Cienc Anim Bras 2010; 11(3): 731-736.

Srivastava R, Ghosh S, Mandal DB, Azhahianambi P, Singhal PS, Pandey NN, et al. Efficacy of Azadirachta indica extracts against Boophilus microplus. Parasitol Res 2008; 104(1): 149-153. PMid:18769940. http:// dx.doi.org/10.1007/s00436-008-1173-3

Vargas M, Céspedes NS, Sánchez HF, Martins JR, Cépedes COC. Avaliaçấo in vitro de uma cepa de campo de Boophilus microplus (Acari: Ixodidae) resistente à Amitraz. Cienc Rural 2003; 33(4): 737-742.

Vieira MIB, Tuerlinckx SM, Santos AB. Avaliação da sensibilidade do carrapato Boophilus microplus a carrapaticidas em rebanhos de corte e leite do município de Bagé, RS, Brasil. Rev Cientif Rural 1998; 3(2):68-74. 